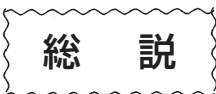

\title{
コイヘルペスウイルス病
}

\author{
湯浅 啓*
}

(2016年 8 月 8 日受付)

\section{Koi Herpesvirus Disease}

\begin{abstract}
Kei Yuasa*
National Research Institute of Aquaculture, Japan Fisheries Research and Education Agency, Mie 516-0193, Japan
\end{abstract}

(Received August 8, 2016)

\begin{abstract}
Koi herpesvirus (KHV) disease caused by cyprinid herpesvirus 3 (CyHV-3) affects carp Cyprinus carpio and its varieties. The disease is listed by the OIE and is also designated as "Specific diseases" in a Japanese law. In Japan, the disease first occurred in 2003 and has quickly spread to all prefectures by distributing infected fish. This review describes basic information on KHV/KHV disease such as its pathogenicity, diagnostic methods, control measures and status of virus distribution in Japan.
\end{abstract}

歴

史

コイヘルペスウイルス（KHV）病とはコイCyprinus carpio とその改良品種であるニシキゴイやカガミゴイが 感染する疾病であり (OIE, 2016), 国際獣疫事務局 (OIE) に2008年にリスト疾病として指定されるととも に, 持続的養殖生産確保法に「特定疾病」として定めら れている。本疾病は1990年代後半にコイに大量死をもた らす疾病としてヨーロッパで認識され，1998年に発生し たイスラエルでの死亡とイスラエルから米国に輸入され たコイでの死亡の両原因がヘルペスウイルスによる感染 症であることが Hedrick et al.（2000）により明らかにさ れた。アジア諸国においては，2002年に中国から輸入し たニシキゴイが感染源とみられる死亡事例がインドネシ アで確認され，その後インドネシア最大のマゴイ養殖生 産地であるチラ夕湖で発生したため, インドネシアのコ イ産業に甚大な被害をもたらした。アジア諸国での発生 を受け，農林水産省は2003年 7 月に本疾病を「特定疾 病」に指定したが, 同年10月に霞ヶ浦マゴイ網生筫養殖 場で大量死が発生し, 翌月11月初旬に増養殖研究所によ り KHV 病と確定診断された。その後, 同法に基づき感

\footnotetext{
水産研究・教育機構増養殖研究所

* Corresponding author

E-mail: yuasa@fra.affrc.go.jp
}

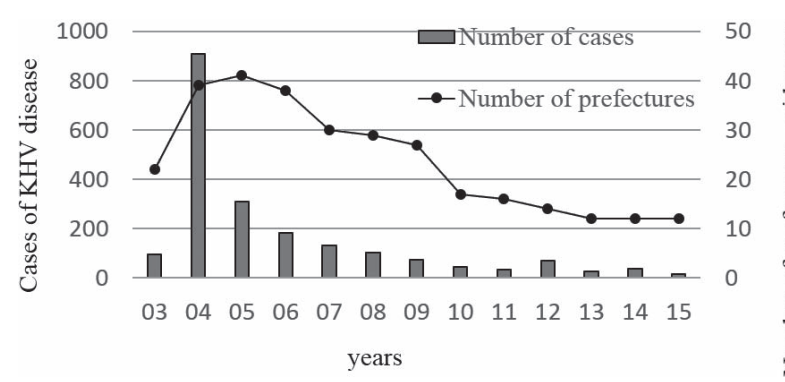

Fig. 1. Cases of KHV disease diagnosed by month in 20032015 (data from home page of Ministry of Agriculture, Forestry and Fisheries).

染水域からの魚の移動制限や感染魚の殺処分等による防 疫措置が実施されたものの，それ以前に感染魚が他県に 流通しており, 同年内に22都府県で KHV の感染が確定 された（飯田・佐野，2005）。冬季に入り水温が下降す ると発生は一旦収束したが, 翌年の春に水温の上昇とと もに全国各地で発生し，39都道府県でKHV 感染が確認 され，確定診断件数は910件に及んだ。その後も前述の 防疫措置は継続され, 平成27年時点での発生件数は17件 にまで減少している。また，ここ数年の発生地域は毎年 十数県で推移している（Fig. 1)。

\section{病原体}

Cyprinid herpesvirus 3 （CyHV-3）が正式名であるが,

年




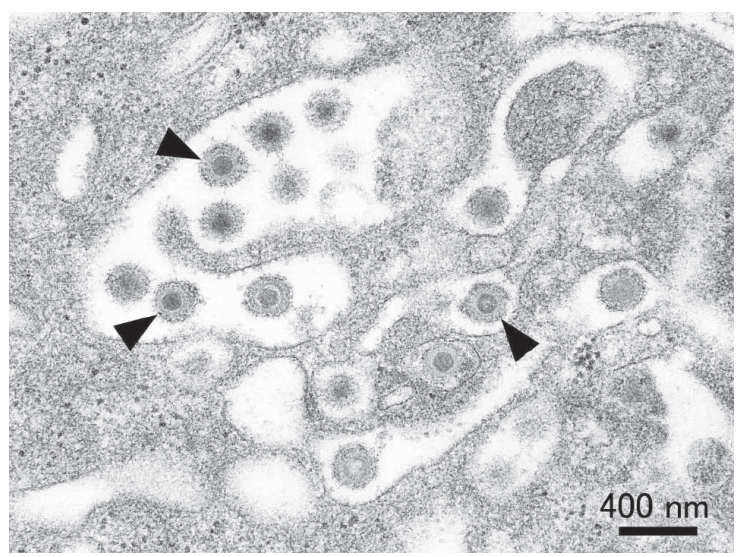

Fig. 2. Mature virions of KHV (arrow head) observed in the Golgi vesicle of cell lines from carp (provided from Dr. Satoshi Miwa).

一般に KHV（koi herpesvirus）とも呼ばれている。アロ ヘルペスウイルス科に分類され，コイのウイルス性乳頭 腫症ウイルス Carp herpesvirus (CHV) (=Cyprinid herpesvirus 1, CyHV-1） やキンギョ造血器壊死症ウイル ス Goldfish hematopoietic necrosis virus (GFHNV) (=Cyprinid herpesvirus 2, CyHV-2) とともにシプリニウ イルス属に属する。成熟ウイルス粒子はエンベロープを 有し直径 170-230 nm の球形を示し, 内部に直径 $110 \mathrm{~nm}$ で正20面体のカプシドを有する（Fig. 2)。ゲノムサイズ は他のヘルペスウイルスより大きく $295 \mathrm{kbp}$ で, CyHV-1 やCyHV-2と $80 \%$ の相同性を示す。成熟過程は一般的な ヘルペスウイルスと同様, 核内でウイルスカプシドが形 成され，成熟カプシドは細胞質のゴルジ小胞体へ移動す る。この際, 小胞体の内膜を取り込みエンベロープが形 成される。小胞体内でエンベロープ上に突起を形成して 成熟し, 細胞質外へ放出される (Miwa et al., 2007)。ウ イルスは KF-1 (koi fin-1) や CCB (common carp brain) 等のコイ由来の細胞で増殖し, 空胞変性 (vacuolation) や合胞体形成 (syncytium) を伴う細胞変性効果 (CPE) を示す (Fig. 3)。一方, キンギョ由来の細胞では CPEが 観察できるものの, KHV の増殖性は低い。培養細胞での ウイルス増殖温度範囲は $15 \sim 25^{\circ} \mathrm{C}$ で $10^{\circ} \mathrm{C}$ または $30^{\circ} \mathrm{C} て ゙$ は増殖できず， $20^{\circ} \mathrm{C}$ が増殖至適温度である。CCB 細胞 内での感染粒子の形成機序について, 感染 6 時間後に mRNA が発現し，12時間後からゲノム DNA が増幅し， 18時間後にコンカテマーが形成され，24時間後に感染粒 子が形成される (Kawato et al., 2014)。遺伝子型は発生 当初からヨーロッパ型（KHV- U; GenBank/DDJB accession No., DQ657948 および KHV-I; accession No., DQ 177346）とアジア型（KHV-J; accession No., AP008984） が存在しており，近年分離されるウイルスも何れかの型 に分類される。

KHV はマゴイやニシキゴイに対して極めて強い病原性

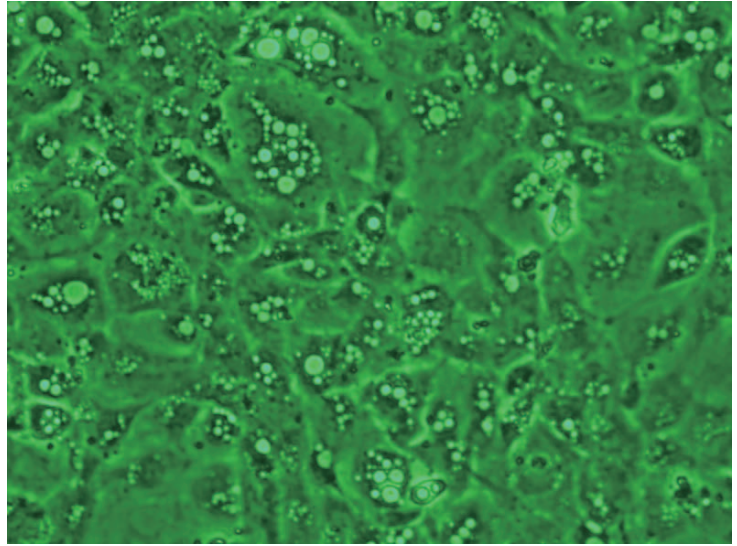

Fig. 3. Cytopathec effect (CPE) observed in CCB cells at 7 days after infection with KHV. Vacuolations in the cytoplasm of CCB cells are observed clearly.

を示し，養殖場だけでなく天然河川や湖沼に生息するコ イに対しても大量死の原因となる。放流用のマゴイ（ヤ マトゴイとも呼ばれる）やニシキゴイとは異なるミトコ ンドリアDNA 型を持つ野ゴイとよばれるマゴイで, よ り高い感受性を示すことが実験的に証明され (Ito et al., 2014），琵琶湖ではこの野ゴイの大量死が2004年に発生 した。コイとキンギョまたはヨーロッパブナの交雑種も KHVに感受性を示すが，コイよりも低い。一方，コイ以 外のコイ科魚類（キンギョも含む）の感受性は無いか極 めて低く, これらがウイルスキャリアーになり感染源と なるか否かについては国際的に議論されているが (Yuasa et al., 2013)，少なくとも国内の現場ではコイ以外が感染 源となった事例は確認されていない。KHVの感染経路は 感染魚から未感染魚への水を介した水平感染が主である。 仔魚に感受性がないことや生殖腺からウイルス検出され ないことから, 経卵感染は起こりにくいものと考えられ る。KHV の魚体への感染門戸は体表で, 体表粘膜上皮で 増殖したウイルスはその後全身の器官へ分布する。脳内 では他器官より遅れてウイルス増殖が見られる。実験感 染では, 感染 7 14日で体内でのウイルス増殖がピーク となり, 死亡に至る。死因のひとつは体表粘膜上皮の剥 離による浸透圧調整の不可と考えられている。生残した 感染耐過魚は免疫を獲得する。KHV の環境水での生存期 間は水質や水温で異なるが, $15^{\circ} \mathrm{C}$ の河川水では 3 日以内 で不活化することが分かっている。エタノールや塩素等 の一般的な消毒剂もウイルス不活化に有効である。死亡 した魚体内各器官でもウイルスは速やかに不活化され, $23^{\circ} \mathrm{C}$ で24時間以内に感染性を失う。一方, $4^{\circ} \mathrm{C}$ では 1 週間, 凍結すれば長期間感染性が保たれる (Yuasa et al., 2012)。

\section{診断法}

KHV 病は外観症状に乏しい。自然感染魚では鰓の部分 


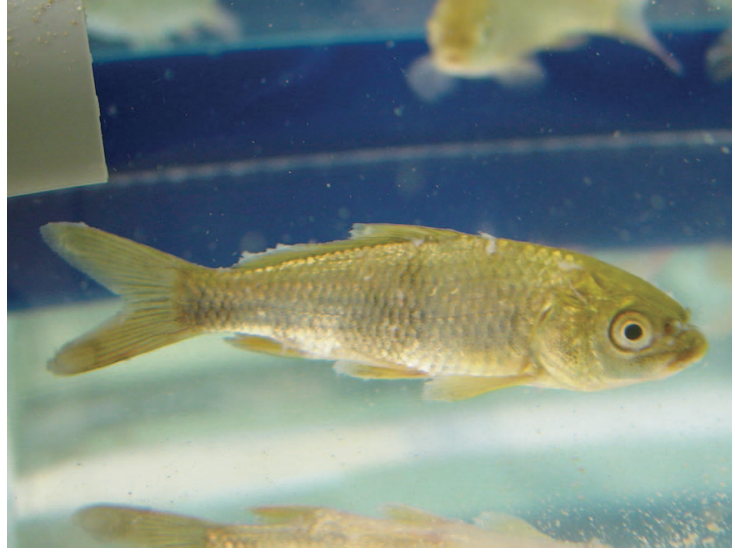

Fig. 4. Common carp experimentally infected with KHV (at 7 days after infection). Infected fish typically shows a swimming behavior with folding up the dorsal fin.

的な壊死，体表のスレや鰭の一部欠損等が確認されるこ とがあるが, 細菌の二次感染を伴う症状である。眼球の 落ち込みが観察される場合もある。人為感染実験では背 鰭を折りたたんだ状態での遊泳（Fig. 4）や体表粘膜上皮 の剥離（Fig. 5）が KHVに特徴的な症状として確認でき るが，現場においてはこれらの観察は難しい。従って， 発生時に症状だけで KHV 病を推定することは難しく, 発 生水温, 死亡状況, 死亡魚種等の情報を含めて判断する 必要がある。培養細胞を用いたウイルス分離は，他の魚 類ウイルス病の診断において最も信頼できる診断法であ るが，死亡した魚体内では KHV 感染粒子が不活化しや すいこと, 感染後期の魚体内では感染粒子が消失するこ と, ウイルス接種した細胞がCPE を示すまで時間を要 すること等の理由で，本疾病の診断には不向きである。 そのため, 国内外に扔いて KHV 遺伝子を検出する PCR 法が診断に用いられている。「特定疾病」である KHV 病 は，国内では「持続的養殖生産確保法」に附属する「病 性鑑定指針」に従って診断される。すなわち，各都道府 県試験場がSph1-5 プライマーを用いたPCR または LAMP 法による一次診断を行い, 続いて増養殖研究所ま たは増養殖研究所により技術の認定を受けた試験場がTK プライマーを用いたPCRによる確定診断を実施する。 PCR を行う際に注意すべき点としてプライマー濃度があ る。特にTK 法においては, 高濃度のプライマーを使用 すると非特異バンドが出現してしまうため, 終濃度を 0.1-0.2 $\mu \mathrm{M}$ に調整する必要がある。PCR 以外の診断で は，魚体血中抗体価を測定する ELISA 法は感染耐過魚の 検出法として注目されている。また, TaqMan realtime PCR が定量 PCR として (OIE, 2016)，RT-PCR がKHV mRNA の特異的検出系として開発されており, 研究分野 で使用されている。高価な輸出用ニシキゴイの無病検査 では，非破壊的に行う必要があることから，「同居法」す なわち検查対象魚と一定期間同居飼育した同居魚を PCR

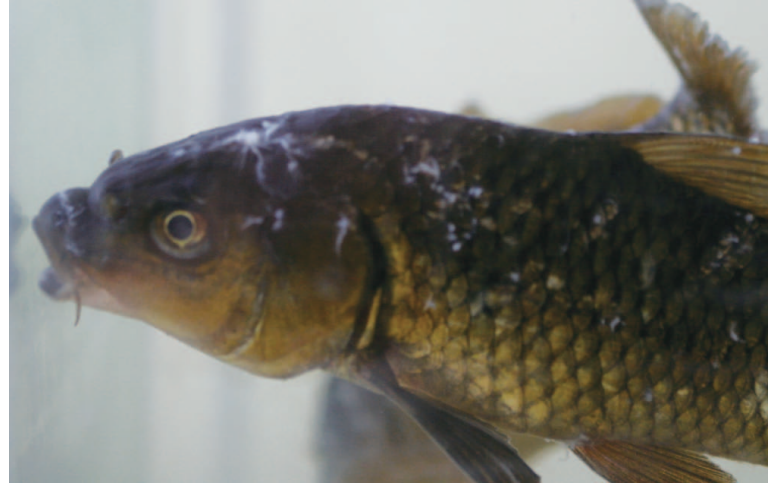

Fig. 5. Common carp experimentally infected with KHV (at 7 days after infection) showing the dead mucosal epithelium shed from body surface.

検査に用いる方法を採用している県もある。同居期間に ついては 2〜3 週間が妥当であることが実験的に示され ている。

\section{防除・予防・治療}

他のウイルス病と同様に本病の治療は困難であるため, 防除や予防に徹する必要がある。感染魚をウイルスフ リー域に持ち込まないことに徹する。KHV 病は特定疾病 であるため, 蔓延防止対策は持続的養殖確保法に従って 行われている。養殖業者は KHV 病の発生が疑われた場 合，都道府県への報告義務を持つ。報告を受けた都道府 県は立入調查や一次診断を行い，その後の確定診断が陽 性であった場合には，感染魚や感染の疑われる魚の移動 制限, 焼却処分, 消毒等の防疫措置を行うことになって いる（農林水産省，2016）。また，国内主要河川・湖沼 については，KHV 污染水域と非污染水域が区分されてお り（ゾーニング）, 発生時以外でも污染または污染の疑わ れる水域から非污染水域へのコイの移動は制限される。 またニシキゴイについては, 輸出業者の養殖施設を対象 にウイルス検査を年 2 回実施し， 2 年間 KHV 陰性であっ た養殖場（コンパートメント）のリストが作成され，リ スト搭載養殖場からコイが輸出されている。ワクチンに ついては，海外では実用化されている国があるが，国内 で認可されたワクチンはない。

治療法として, 飼育水温を数日間 $30^{\circ} \mathrm{C}$ 以上に保つ「昇 温法」が有効とされているが， $30^{\circ} \mathrm{C}$ でウイルスは不活化 せず，ウイルスキャリアーになる可能性が否定できない。 免疫獲得魚はその後の感染に対して抵抗性を示すことか ら, 人為感染後に「昇温法」を施して免疫獲得魚を作出 する方法が開発されているが, 感染時のウイルス感染価 や昇温のプログラムにより免疫獲得効果にばらつきが見 られ，また作出された魚がウイルスキャリアーとなり， 次の感染源となるという問題も残されている。 


\section{最近の研究動向・残された課題}

今後もウイルスフリー魚の流通が KHV 防除には不可 欠であり, より精度の高い検査法が求められている。ま た，ニシキゴイの検査では未感染魚の準備を必要とする 「同居法」に代わる非破壊検査法を用いたより簡易な検査 法の開発が望まれている。感染魚の体表粘膜上皮には他 器官より高濃度のウイルスが存在するが分かっており (Monaghan et al., 2015)，今後非破壊的に体表粘膜上皮 を採取する方法について検討する必要がある。一方，污 染水域，特に湖上での網生筫養殖の場合，免疫獲得した 種苗を使用する必要があり，実用的かつ安全性の高いワ クチンの開発あるいはウイルスキャリアーとはならない 免疫魚の作出法の開発が望まれる。実験的にはDNAワ クチンの効果（Zhou et al., 2014）や抗 KHV 鶏卵抗体の 経口投与による予防効果が示されている (Liu et al., 2014）。また，コイの腸内や環境水に生息する細菌によ り KHV は不活化されることから (Yoshida et al., 2013), 砂滤過槽の設置により KHV 污染水のウイルスを不活化 できる可能性が示唆されている。

KHVの宿主域に関し，近年フナ属の Siberian crucian carp Carassius auratus から KHV 遺伝子が検出されてい る (Cho et al., 2014)。本魚種体内でウイルスは増殖する のか, あるいはウイルスに暴露された魚がウイルスキャ リアーになるのかについて, 今後検証する必要がある。 また，近年，オランダに輸入されたコイから KHV と類 似したウイルス遺伝子が検出されているが (Marc et al., 2013), 分離されていないためにその病原性は不明であ る。今後，高感受性を有する細胞を開発するとともに， それらを用いたウイルス分離を実施していく必要がある。

\section{文献}

Cho, M. Y., K. M. Won, J. W. Kim, B. Y. Jee, M. A. Park and S. Hong (2014): Detection of koi herpesvirus (KHV) in healthy cyprinid seed stock. Dis. Aquat. Organ., 112, 29-36.

Hedrick, R. P., O. Gilad, S. Yun and A. V. Spangenberg (2000): A herpesvirus associated with mass mortality of juvenile and adult koi, a strain of common carp. J.Aquat. Anim. Health, 12, 44-57.
飯田貴次・佐野元彦（2005）：コイヘルペスウイルス病。 ウイ ルス, 55, 145-152.

Ito, T., J. Kurita and K. Yuasa (2014): Differences in the susceptibility of Japanese indigenous and domesticated Eurasian common carp (Cyprinus carpio), identified by mitochondrial DNA typing, to cyprinid herpesvirus 3 (CyHV-3). Vet. Microbiol., 171, 31-40.

Kawato, Y., K. Yuasa, Y. Shimahara and N. Oseko (2014): Detection and application of circular (concatemeric) DNA as an indicator of koi herpesvirus infection. Dis. Aquat. Organ., 112, 37-44.

Lui, Z., H. Ke, Y. Ma, L. Hao, G. Feng, J. Ma, Z. Liang and Y. L (2014): Oral passive immunization of carp Cyprinus carpio with anti-CyHV-3 chicken egg yolk immunoglobulin (IgY). Fish Pathol., 49, 113-120.

Marc, Y., M. Y. Engelsma, K. Way, M. J. Dodge, M. VoorbergenLaarman, V. Panzarin, M. Abbadi, M. El-Matbouli, H. F. Skall, S. Kahns and D. M. Stone (2013): Detection of novel strains of cyprinid herpesvirus closely related to koi herpesvirus, Dis. Aquat. Organ., 107, 113-120.

Miwa, S., T. Ito and M. Sano (2007): Morphogenesis of koi herpesvirus observed by electron microscopy. J. Fish Dis., 30, 715-722.

Monaghan, S. J., K. D. Thompson, A. Adams and M. Bergmann (2015): Sensitivity of seven PCR for early detection of koi herpesvirus in experimentally infected carp, Cyprinus carpio L., by lethal and non-lethal sampling methods. J. Fish Dis., 38, 303-319.

農林水産省消費 - 安全局畜水産安全管理課水産安全室（2016）： 水産防疫体制の強化について. Fish Pathol., 51, 75-87.

OIE (the World Organisation for Animal Health) (2016): Chapter 2.3.7. Koi herpesvirus disease in Manual of diagnostic tests for aquatic animals 2016, http://www.oie.int/index.php? id $=2439 \& \mathrm{~L}=0$ \&htmfile=chapitre koi herpesvirus. htm

Yoshida, N., R.-K. Sasaki, H. Kasai and M. Yoshimizu (2013): Inactivation of koi herpesvirus in water using bacteria isolated from carp intestines and carp habitats. J. Fish Dis., 36, 997-1005

Yuasa, K., M. Sano and N. Oseko (2012): Effective procedures for culture isolation of koi herpesvirus (KHV). Fish Pathol., 47, 97-99.

Yuasa, K., M. Sano and N. Oseko (2013): Goldfish is not a susceptible host of koi herpesvirus (KHV) disease. Fish Pathol., 48, 52-55.

Zhou, J. X., H. Wang, X. W. Li, X. Zhu, W. L. Lu and D. M. Zhang (2014): Construction of KHV-CJ Orf25 DNA vaccine and immune challenge test. J. Fish Dis., 37, 319-325. 